\title{
Синтез InAlAs/InP гетероструктур для приборов радиофотоники
}

\author{
Д.А. Колосовский ${ }^{1,2)}$, Д.В. Дмитриев ${ }^{1)}$, А.И. Торопов ${ }^{1)}$, А.М. Гилинский ${ }^{1)}$, Т.А. Гаврилова ${ }^{1)}$, \\ А.С. Кожухов ${ }^{1)}$, К.С. Журавлев ${ }^{1)}$ \\ ${ }^{1}$ Институт физики полупроводников им. А.В. Ржанова СО РАН, \\ Новосибирск, 630090, пр. Ак. Лаврентьева, 13 \\ ${ }^{2}$ НГУ, Новосибирск, 630090, Пирогова, 2 \\ тел:+7 (913) 954-5584, эл.nочта: danil-ak@yandex.ru
}

DOI 10.34077/RCSP2019-106

Гетероэпитаксиальные структуры (ГЭС) InAlAs/InP согласованные по параметрам кристаллической решетки нашли свое применение в современных оптоэлектронных и СВЧ приборах используемых в новом научно-техническом направлении - радиофотоника [1-4]. При создании таких приборов необходимо учитывать характеристики ГЭС. В работе [5] показано, что качество ГЭС влияет на параметры приборов. Для транзисторных структур большое количество дефектов ведет к большим токам утечки, а в случае фотодиодных и лазерных структур к большим темновым токам [6]. В работе представлены условия синтеза эпитаксиальных слоёв InAlAs/InP с плотностью структурных дефектов меньше чем $10^{4} \mathrm{~cm}^{-2}$.

Синтез ГЭС проводился методом молекулярно-лучевой эпитаксии (МЛЭ) на установке Riber Compact-21T на подложках (001)InP в диапазоне температур $450-560^{\circ} \mathrm{C}$ в потоке мышьяка, варьирующемся в диапазоне от $10^{-6}$ до $6 \times 10^{-5}$ Торр. Отношение потока материалов третьей группы (In и $\mathrm{Al})$ подбиралось для получения решеточно-согласованого, с подложкой $\mathrm{InP}$, состава $\mathrm{X}=0.52$. Состав ГЭС контролировался методом фотолюминесценции (ФЛ). Морфология поверхности характеризовалась методом атомно-силовой микроскопии (АСМ). Структурный анализ слоев проводился методом сканирующей электронной микроскопии (СЭМ).

В работе показано, что на согласованных по параметру кристаллической решётки ГЭС InAlAs/InP наблюдается плотность ростовых дефектов от $8 \times 10^{4}$ до $1 \times 10^{7} \mathrm{~cm}^{-2}$. При отклонении от решеточносогласованого состава плотность дефектов может достигать $10^{9} \mathrm{~cm}^{-2}$. Показано, что наименьшая плотность дефектов наблюдается при температурах роста $500-510^{\circ} \mathrm{C}$ и отношении потока мышьяка к потокам элементов третьей группы не ниже 75. На СЭМ изображениях поперечного скола ГЭС видно, что дефекты образованы выходами дислокаций из гетерограницы InAlAs/InP. Вероятно, дислокации появились в результате замещения атомов фосфора атомами мышьяка в процессе высокотемпературного отжига подложки InP. Замещение мышьяком фосфора приводит к образованию островков InAs и решеточному рассогласованию на начальных этапах роста InAlAs слоя. Возникающие напряжения в кристаллической решетке, релаксируют в виде дислокаций. Известно, что дефекты, прорастающие из подложки, могут замыкаться на гетерограницах [7]. Поэтому были использованы буферные сверхрешетки InAlAs/InGaAs, что привело к снижению плотности дефектов на 1-2 порядка. На АСМ картинах таких слоёв видны моноатомные ступени, среднеквадратичное значение шероховатости не превышает 0.6 нм.

Используя разработанную технологию эпитаксиального роста, были получены ГЭС для СВЧ фотодиодов и электро-оптических модуляторов Маха-Цендера.

АСМ и СЭМ исследования проводились на оборудовании ЦКП «Наноструктуры».

\section{Лumepamypa}

[1] D.-H. Kim, J.A. delAlamo, // IEEE Trans. Electron Dev., 2010. V. 57, pp. 1504-1511.

[2] D.-H. Kim, J.A. delAlamo, // IEEE Trans. Electron Dev., 2010. V. 31, pp. 806-808.

[3] P. Gutowski, I. Sankowska, // Journal of Crystal Growth, 2017. V. 466, pp. $22-29$.

[4] Д.В. Дмитриев, А.И. Торопов // Труды XXV международной научно-технической конференции и школы по фотоэлектронике и приборам ночного видения, 2018, с. 57-59.

[5] I.B. Chistokhin, M.S. Aksenov, // Materials Science in Semiconductor Processing, 2018. V. 74, pp. 193198.

[6] G. Karve, X. Zheng, // IEEE Journal of Quantum Electronics, 2003. V.39, pp. 1281-1286.

[7] Leroy L. Chang and K. Pkoog, // Martinus Nijhoff Publisher, 1985. P. 719. 